\title{
THE USE OF ANIMATION CLIPS AS MEDIA IN TEACHING WRITING
}

\author{
Moh. Choirul Huda ${ }^{1}$, Willy Anugrah Gumilang ${ }^{2}$ \\ STKIP PGRI Tulungagung, Indonesia \\ E-mail: $\underline{\text { choirul.huda@stkippgritulungagung.ac.id, }{ }^{2} \text { osmondwilliam@gmail.com }}$
}

\author{
Submit: 24-09-2018 Review: 01-10-2018 Accepted: 08-10-2018
}

DOI: https://doi.org/10.22202/tus.2019.v5i1.2888

\begin{abstract}
This study is aimed at describing the implementation of animation clips as a media in teaching writing to the eleventh grade students of Madrasah Aliyah (MA) Sunan Giri Gondang in academic year 2017/2018, how is the students' writing score after being taught using Animation clips, and problems faced by the teacher in teaching writing using animation clips. This research is a descriptive qualitative research. The subjects are the teacher and the eleventh grade students of MA Sunan Giri Gondang in academic year 2017/2018 totally 20 students. The instruments used in this research are test, observation checklist, and interview guide. The result shows that the implementation of animation clips in teaching writing is successful. The students' writing score is getting better after being taught using Animation clips. The mean score in pre-test is 74 while in post-test is 79. Based on the data taken from interview with the English teacher and the students after animation clips was implemented in their writing class, it can be described that applying animation clips in writing class has some advantages such as the class is easy to manage, the students feel free to select the writing topic, etc. Besides, there are some disadvantages of it such as it needs more cost, it needs a lot of bandwidth, etc
\end{abstract}

Keywords: animation clips, writing

\section{INTRODUCTION}

English takes an important role in this global era as it forces the education in Indonesia to prepare the students to master English. Facing global era, Indonesia's government made rules that English subject has to be taught since junior high school which is stated in PP RI No. 19 Tahun 2005 about The Standard of National Education revised in PP RI No.32 Tahun 2013 that in the level of SMP / MTs /SMPLB, or other equals, National Examination covers Indonesian, English, Mathematics, and Sciences. Even though students have been 
learning English since junior high school, most of them have problems to master English because there are four skills that must be learnt, such as; listening, speaking, reading, and writing. Sometimes, writing is considered as the most difficult skill for the students because based on syllabus it is learnt after speaking, listening, and reading. It is in line with Nunan (1989) in (Fareed, Ashraf, \& Bilal, 2016) states that writing is an extremely difficult cognitive activity which requires the learner to have control over various factors. These factors vary from academic background and personal interest of the writer. Then it will absolutely be the teachers' heavy duty in teaching writing.

According to (Waloyo, 1999), teaching writing is absolutely not easy because the teachers have to guide the students on constructing paragraph patiently. The teachers also have to facilitate the students with appropriate technique that can stimulate, motivate them in expressing their ideas. It is noteworthy that developing students' English language writing skills can be a challenging task for any teacher (Almubark, 2016). Furthermore, the teachers have to solve the students' problems that occur in process of writing. In addition, Gunawan (2002) states that teachers tend to teach students about word formation, vocabulary, grammar, theories of writing, and thus ignoring the practice of writing. Therefore, it is needed for teacher to always explore and make an experiment all about teaching writing. Teacher has a big role on the students' learning process. According to (Harrison \& Killion, 2008) there are 10 roles of teacher in teaching and learning process such as resource provider, curriculum specialist, learning facilitator, classroom supporter, mentor, instructional specialist, school leader, and learner. Therefore, teacher has large opportunities to help the students succeed in their learning.

In teaching and learning process, the teacher cannot be separated from the media of teaching. According to (Heinich, et al. 1996) in (Naz \& Akbar, 2010), the most common use of media in an instructional situation is for supplemental support of the instructor in the class room to enhance learning. Hence, media takes an important role to the students' success in learning. Nowadays, there are many 
experts who always try to explore and discover various media for teaching. Therefore, there are many options for teacher to choose various kinds of media for teaching. All media are good since it is appropriate with the needs of the class.

In this research, the researcher focuses the research on the use of Animation Clips in teaching writing. According to (Cahyono, B.Y \& Kusumaningrum, 2011), animation clip is a film that the pictures seem to be really moving and the duration of the moving pictures is no more than 10 minutes. Animation clip is a kind of video, but the duration is shorter than the video. It comes with no spoken language but only action and gesture. Therefore, it is appropriate to be applied in writing class. The actors' gesture, action, and expression can stimulate the students' mind in getting ideas. It is very fun because the students can express the actors' action with their own words and they can name the actors with any name they like.

The implementation of animation clips in teaching writing is based on (Harmer, 2004) reviewed in (Laborda, 2006) that there are four step how to teach writing; (1)Planning, writers plan what they are going to write, such as topic or outlines. In this phase, writers have to consider about some main issues, such as considering the purpose of their writing. Not only the type of the text, but also the chosen language they will use, and the information they should be included. Besides, the writers should think of the audience, it will influence not only the shape of the writing, but also the choice of language. As instance, it should use formal or informal tone. Furthermore, writers must consider its content structure, which will result to how best the sequence of the fact, ideas, or arguments included. (2) Drafting, it refers to the first version of the text as a draft. It is often done on the assumption that it will be revised later. It becomes material which will be edited. Several drafts may be created for one final version. (3) Editing (reflection and revising), after producing a draft, they then read the whole text to see whether there is part which is appropriate or not. Some parts or paragraphs that are considered to be confusing or ambiguous then can be moved or even changed with the new words or sentence. Reflecting and revising are sometimes 
helped by other readers' comments and suggestions. (5) Final version, in this phase, the edited draft then becomes final version of the text or writing. It absolutely may be different from both the original plan and the first draft, because many things have changed in the editing process.

There are some reasons why the teacher should use animation clips as media for teaching writing. According to (Kim, Yoon, Whang, Tversky, \& Morrison, 2007), the effects of animation on learning are: (a) Animations might be more attractive and motivating, (b) The animated graphics portrayed more information than the static ones, (c) Motion itself attracts attention, (d) Animated graphics, in essence, have seductive details that increase emotional interest.

From the previous research dealing with animation clips, it also has some advantages when it is applied in writing class. According to (Cahyono, B.Y \& Kusumaningrum, 2011), there are some advantages of using animation clip as media, such as: to increase the students' motivation, to prevent the students' boredom in the following learning process, to attract the students' interest in teaching and learning process, if they interested in learning, the result of their writing performance will also be good, to make a good atmosphere during the teaching and learning process.

Based on the background above, the problem of the research can be formulated as follow: (1) how is the eleventh grade students' writing score after being taught using animation clips?, (2) how is the implementation of animation clips as media to the eleventh grade students of Madrasah Aliyah (MA) Sunan Giri Gondang in academic year 2017/2018?, (3) what are the problems faced when employing animation clips in writing class?

\section{METHODS}

The design of this research is descriptive qualitative. This design is used for this study is aimed at describing the media, Animation Clips, applied by the teacher in teaching writing. The researcher observed the teaching and learning process done by the teacher naturally. The data collected were in the form of 
quantitative and qualitative. Then, they were analyzed through data reduction, data display and drawing conclusion.

The subject of this research was the teacher and the eleventh grade students of Madrasah Aliyah (MA) Sunan Giri Gondang in academic year 2017/2018 which consisted of 20 students. The location was at MA Sunan Giri Gondang Tulungagung on Jl. Raya Tulungagung-Trenggalek km 13. MA Sunan Giri Gondans is the integrated school with SMPI Sunan Giri and Islamic boarding school Miftakhul Ulum. The method of data collection were using test (pre-test and post test), observation checklist, and interview guide. To analyze the students' score, it was used the modified scoring rubric adapted from (Heaton, 1988) reviewed in (Uztosun, 2006), see the table 1 below.

Table 1. Scoring Rubric of writing test

\begin{tabular}{|c|c|c|c|}
\hline $\begin{array}{c}\text { Components of } \\
\text { Writing }\end{array}$ & Score & Level & Indicator \\
\hline \multirow[t]{4}{*}{ Content } & 4 & Excellent & $\begin{array}{l}\text { Present the information well chosen details } \\
\text { across the paragraph }\end{array}$ \\
\hline & 3 & Good & $\begin{array}{l}\text { Present the information with details in } \\
\text { parts of the paragraph }\end{array}$ \\
\hline & 2 & Fair & Present the information with some details \\
\hline & 1 & Poor & Present no clear information \\
\hline \multirow[t]{4}{*}{ Vocabulary } & 4 & Excellent & Good in vocabulary choice \\
\hline & 3 & Good & $\begin{array}{l}\text { Error in vocabulary choice are few and do } \\
\text { not interfere with understanding }\end{array}$ \\
\hline & 2 & Fair & $\begin{array}{l}\text { Error in vocabulary choice are and } \\
\text { sometimes they interfere with } \\
\text { understanding }\end{array}$ \\
\hline & 1 & Poor & $\begin{array}{l}\text { Many error in vocabulary choice that } \\
\text { severally interfere with understanding }\end{array}$ \\
\hline \multirow[t]{4}{*}{ Grammar } & 4 & Excellent & Good in grammar \\
\hline & 3 & Good & $\begin{array}{l}\text { Error in grammar choice are few and do } \\
\text { not interfere with understanding }\end{array}$ \\
\hline & 2 & Fair & $\begin{array}{l}\text { Error in grammar choice are and } \\
\text { sometimes they interfere with } \\
\text { understanding }\end{array}$ \\
\hline & 1 & Poor & Many error in grammar choice that \\
\hline
\end{tabular}




\begin{tabular}{cccl}
\hline Mechanics & 4 & Excellent & $\begin{array}{l}\text { Good in spelling, punctuation and } \\
\text { capitalization } \\
\text { Error in spelling, punctuation and } \\
\text { capitalization are few } \\
\text { Error in spelling, punctuation and } \\
\text { capitalization, and sometimes interfere } \\
\text { with understanding } \\
\text { Error in spelling, punctuation and } \\
\text { capitalization and severely interfere with } \\
\text { understanding }\end{array}$ \\
& Foor & Fair & \\
& &
\end{tabular}

\section{FINDING AND DISCUSSION}

From the first observation, it can be described that the teacher and researcher entered the class, the students were noisy and most of the students were not in the class, the leader of the class called several students comes to the class. The teacher started the class by greeting them and introduced the researcher to the students. After that the teacher checked the attendance list; there was 1 student who were absent in that day and the class consisted 19 students.

Before starting teaching learning process, the teacher did flash review about narrative text. The review was done by giving questions and the students answered orally. Only 1 or 2 who always answer the teacher's question. After giving review, then the teacher gave pre-test to the students. The time allotment was 80 minutes to finish their work. The test consisted of one item with the instruction of creating narrative text based on the topics provided. There were some students who could not finish their work on time but finally all the students could finish and submit their work. Here is the result of the students' pre test, see on the table 2 below. 
Table 2 The students' writing score (pre-test)

\begin{tabular}{|c|c|c|c|c|c|c|}
\hline \multirow{2}{*}{ Students } & \multicolumn{4}{|c|}{ Category } & \multirow{2}{*}{ Total } & \multirow{2}{*}{ Final Score } \\
\hline & $\mathbf{C}$ & $\mathbf{V}$ & $\mathbf{G}$ & $\mathbf{M}$ & & \\
\hline 1 & 2 & 3 & 2 & 4 & 11 & 69 \\
\hline 2 & 2 & 2 & 4 & 3 & 11 & 69 \\
\hline 3 & 3 & 4 & 2 & 3 & 12 & 75 \\
\hline 4 & 3 & 3 & 3 & 3 & 12 & 75 \\
\hline 5 & 2 & 3 & 2 & 3 & 10 & 63 \\
\hline 6 & 4 & 3 & 2 & 3 & 12 & 75 \\
\hline 7 & 3 & 3 & 2 & 4 & 12 & 75 \\
\hline 8 & 4 & 3 & 3 & 3 & 13 & 81 \\
\hline 9 & 3 & 3 & 3 & 4 & 13 & 81 \\
\hline 10 & 3 & 3 & 2 & 3 & 11 & 69 \\
\hline 11 & 4 & 3 & 2 & 3 & 12 & 75 \\
\hline 12 & 4 & 2 & 3 & 3 & 12 & 75 \\
\hline 13 & 3 & 3 & 2 & 3 & 11 & 69 \\
\hline 14 & 3 & 3 & 3 & 4 & 13 & 81 \\
\hline 15 & 3 & 3 & 3 & 3 & 12 & 75 \\
\hline 16 & 3 & 3 & 3 & 4 & 13 & 81 \\
\hline 17 & 3 & 3 & 2 & 3 & 11 & 69 \\
\hline 18 & 3 & 3 & 3 & 4 & 13 & 81 \\
\hline 19 & 3 & 3 & 3 & 3 & 12 & 75 \\
\hline 20 & 3 & 3 & 2 & 3 & 11 & 69 \\
\hline \multicolumn{6}{|c|}{ Total } & 1481 \\
\hline \multicolumn{6}{|c|}{ Mean } & 74 \\
\hline
\end{tabular}

From the table 2 above, it can be concluded that the students' mean score before being taught using Animation clips is 74. It is the average score of the total students which was calculated by using formula: Mean $=\frac{1481}{20}$. The highest score is 81 and the lowest score is 63 . There are 4 students who get 81 and there is 1 student who gets 63 . The next step was to do treatment by using animation clips media in teaching writing.

In the next phase on different day, the teacher applied animation clips as media for teaching. The procedure applied can be described below.

1) The teacher divides the students into groups which consist of two students in each group. 
2) The teacher asks the students to access the website:

https://www.teachingideas.co.uk/activity-types/video

3) The students then can choose an Animation Clips they like.

4) The teacher asks the students to access the website: http://www.videonot.es/

5) The students then can watch the Animation Clips while making notes in the space provided (not in paper)

6) The students may repeat and or pause the clips at will

7) Once the students finish writing and revising their work, the students are asked to save their work using Google drive. (the students should have gmail account first)

8) Share the project by sending the Google drive link to the teacher.

Meanwhile the time allotment was 2 hours meeting or 80 minutes. The teaching scenario can be seen in the table 3 below.

\section{Table 3. The Teaching Scenario of Animation Clip in Writing Class}

\begin{tabular}{|c|c|c|}
\hline No & Activities & Time \\
\hline 1 & $\begin{array}{l}\text { Pre-Activities ( Opening ) } \\
\text { - Teacher greets the students } \\
\text { - Teacher asks the students' condition } \\
\text { - Teacher gives review about previous lesson }\end{array}$ & 5 minutes \\
\hline 2 & $\begin{array}{l}\text { Whilst Activities ( Main Activities ) } \\
\text { - The teacher gives review about writing narrative } \\
\text { text } \\
\text { - The teacher explains the procedures how to apply } \\
\text { Animation Clips in Writing as follow: } \\
\text { 1) Access the website: } \\
\text { https://www.teachingideas.co.uk/activity- } \\
\text { types/video } \\
\text { 2) Decide one Animation Clips provided } \\
\text { 3) Access the website: } \\
\text { http://www.videonot.es/ } \\
\text { 4) Let the students take notes in space } \\
\text { provided based on the clips. } \\
\text { 5) Make the students to develop the notes to } \\
\text { be a full story based on the clips }\end{array}$ & 60 minutes \\
\hline
\end{tabular}


6) Save and share the project.

$3 \quad$ Post Activity

- The teacher asks the students to submit their final compositions.

- The teacher gives summary dealing with the students' work

- Teacher reviews in a brief about the use of past tense, the words that show the order of events, and generic structures of a narrative text.

Based on the observation the researcher did when teaching and learning process, it can be described that the students could follow the activities well. The little problem appeared when there were some students who could not operate computer well. The teacher then should guide them to operate but at last it could be handled well.

In the process of writing activity, it looked that the students feel enthusiastic. It can be seen when the students actively discussed with their group talking about the animation clips watched. Besides, automatically the students were also doing the steps of learning writing well, i.e. planning, drafting, revising, and final version. It can be seen when the students tried hard to play and pause the clips in many times. Once they finished doing their work, then they submitted their work. Only 1 group who was late to submit but finally all the groups could submit their work well.

Post-test then was given in the following meeting. The students were directly entering to computer lab then doing the writing activity by following the procedures as like before. The test session could run well. It can be seen from the students' performance to operate computer and do the task. There is no serious problem in this phase. They could do by themselves and submit on time. The students' writing score can be described below (see on table 4).

Table 4. The students' writing score (post-test) 


\begin{tabular}{ccccccc}
\hline \multirow{2}{*}{ Students } & \multicolumn{9}{c}{ Category } & Total & Final Score \\
\hline 1 & $\mathbf{C}$ & $\mathbf{V}$ & $\mathbf{G}$ & $\mathbf{M}$ & & 75 \\
2 & 3 & 3 & 2 & 4 & 12 & 75 \\
3 & 3 & 2 & 4 & 3 & 12 & 81 \\
4 & 4 & 4 & 2 & 3 & 13 & 81 \\
5 & 3 & 4 & 3 & 3 & 13 & 69 \\
6 & 3 & 3 & 2 & 3 & 11 & 81 \\
7 & 4 & 4 & 2 & 3 & 13 & 88 \\
8 & 4 & 4 & 2 & 4 & 14 & 88 \\
9 & 4 & 4 & 3 & 3 & 14 & 88 \\
10 & 3 & 4 & 3 & 4 & 14 & 75 \\
11 & 4 & 3 & 2 & 3 & 12 & 81 \\
12 & 4 & 3 & 3 & 3 & 13 & 75 \\
13 & 4 & 3 & 3 & 3 & 13 & 88 \\
14 & 3 & 4 & 2 & 3 & 12 & 75 \\
15 & 4 & 3 & 3 & 4 & 14 & 88 \\
16 & 3 & 3 & 3 & 3 & 12 & 69 \\
17 & 4 & 3 & 3 & 4 & 14 & 81 \\
18 & 3 & 3 & 2 & 3 & 11 & 75 \\
19 & 4 & 3 & 2 & 4 & 13 & 75 \\
20 & 4 & 3 & 2 & 3 & 11 & 1588 \\
\hline & 4 & 2 & 3 & 3 & 11 & \\
\hline & & Total & & & & \\
\hline
\end{tabular}

From the table above it can be seen that the mean score in pre-test is 74 , meanwhile the mean score in post-test increases to $\frac{1588}{20}=79$. The highest score is 88 and the the lowest score is 69 . There are 5 students who get 88 and 2 students who get 69. In general, if it is compared with the students' score in pretest, it can be concluded that the students' writing score is getting better after being taught using Animation Clips.

Based on the researcher's interview with the teacher and some students dealing with the implementation of animation clips, it can be known that there are some advantages and disadvantages of animation clips applied in writing class. The result of the interview with the English teacher of Madrasah Aliyah Sunan Giri Gondang can be seen below. 
"Is animation clips difficult to be employed in writing class? Why?"

The teacher answered, "not really". Her reason was that animation clips is actually easy to be employed in writing class. The problems appeared when there were some students who were less familiar with the computer and internet then she had to guide to operate the computer and internet first. As instance, how to type some specific characters using keyboard, how to access internet using an application on computer, how to run some applications, etc. From this data it can be concluded that animation clips is easy to apply in writing class since the students have been familiar with computer and internet technology.

"Does animation clips help you much in managing your class?

Why?"

The teacher answered "yes", and her reason was that when she applied animation clips in her class, the students were focused on facing their computer in front of them and tried to do the teacher's instructions well. The students seemed enjoying the lesson while watching the clips. Hence, she was not busy to ask the students to pay attention to the lesson given. From this data it can be assumed that using animation clips can help the teacher in making the class more conducive or easy to manage.

"What were the difficulties you found in running some applications which are related to animation clips"?

She answered that there were some difficulties she faced when running some applications, such as she got problem in using "sli.do" and also she sometimes confused to connect www.videonot.es to "gmail" account then opened the students' project in it. This data shows that animation clips is difficult to apply since the teacher is not familiar in using some related computer applications.

"Is scoring the students' work via online application reliable and appropriate with your scoring rubric or criteria?"

She answered that scoring the students' writing using online application was really helpful besides offline method. It can support the scoring result from offline method. The result from online system was reliable and fit with what she 
wanted to score and matched with the scoring criteria she wanted. Based on this data it can be concluded that by applying animation clips in writing class can help the teacher score the students' writing more easily.

"Do animation clips provided by www.teachingideas.co.uk cover the students' need?"

She answered, "not really", because sometimes it did not provide an appropriate material or topic. For example, it is difficult to find an animation clips consisting of Indonesian culture topic. From this data it can be assumed that it is sometimes difficult to get animation clips with appropriate topic desired.

"Do you think that it is difficult to create animation clips as you want? Why?"

She answered, "Absolutely yes". The reason was that she did not have knowledge and experience in creating the animation clips hence it is very difficult for her to create. This data shows that the teacher can only adopt the animation clips from a certain online source because it is difficult to create the animation clips herself because the teacher must have certain programming technology and experiences to implement the animation programs.

"Do the teachers need to create animation clips themselves

when having plan to apply it in their writing class?

She answered, "not really", but for her opinion it is needed to be able to create animation clips ourselves because it can be an alternative where the animation clips provided by certain sources do not fit with the students' need anymore and we as teacher want to provide an appropriate animation clips for them. It can be concluded that the teacher does not need to create animation clips herself since the topic provided by the online source is appropriate for the students.

Meanwhile, the result of the interview with some students can be described below.

“Apakah kamu suka kegiatan menulis dengan menggunakan

animation clips?Mengapa?” 
(Do you like writing activity using animation clips? Why?)

Students A answered that he liked learning writing using computer and animation clips because he likes computer technology and it seemed easier learning with it than with traditional method. Meanwhile, student B answered that she liked it because it was fun. This data shows that animation clips is enjoyable and fun for students in learning writing.

“Aktifitas apa saja yang sangat kamu suka ketika dalam

kelas writing dan guru menggunakan animation clips

sebagai media?

(What activities do you like most when having writing class

and the teacher uses animation clips as media?")

Student A answered that he liked watching animation clips because he can selected the animation clips he liked. Student B answered that she liked watching the animation clips while writing the story about it. This data shows that the students can learn writing while watching animation clips.

“Apakah kamu menemui kesulitan ketika menulis paragraf

di www.videonot.es dan mengumpulkan hasil tulisan kamu

ke guru? Jelaskan!

(do you find difficulties in writing paragraph in

www.videonot.es and submit it to your teacher? Explain.)

Student A answered that he could easily write a paragraph in www.videonot.es and he was also easy to submit his work via Gmail account. Student B answered that she sometimes got difficulties in typing and she was less familiar using desktop keyboard hence she was bit longer to type and finish her paragraph. In other word, it is sometimes difficult to apply animation clips in writing class when the students themselves are low in technology experience.

"Apa yang tidak kamu sukai dari penggunaan media animation clips yang digunakan dalam kelas writing?"

(what are the things you do not like from the usage of animation clips in writing class? 
Student A answered that he was annoyed when the internet connection was down because it made the clips stop playing. Student B answered that it was very annoyed when she had to type slowly with the desktop keyboard. From this data, it can be assumed that animation clips needs a lot of bandwidth to access, hence, it will take too long to show over a slow_internet connection.

Apakah kamu menggunakan "google translate" untuk mentranslate tulisanmu?Mengapa?

(Do you use "google translate" to translate your writing? Why?)

Student A answered that he used google translate to translate his writing because it was easier and the teacher do not know when he used it. Student B answered that she used google translate as well because she only needed to copy and paste her writing. Hence, it was easy and fast to translate. From this data it can be concluded that it provides the chance for the students to cheat using google translate to translate their writing.

According to the analysis above, it can be concluded that animation clips have some advantages and disadvantages. The outline advantages of animation clips can be described below.

a. The class is easy to manage

b. The students can find and choose the topic they like easily

c. The students do not need to write on paper

d. The students can watch and write simultaneously

e. The students do not need to worry to lose their work because it is saved in cloud drive.

f. The students can continue their work anytime and anywhere with different computer since they can access their cloud drive (google drive)

g. The students can consult to the teacher via online.

h. The students can submit their work even they are in a far distance with the teacher.

i. The teacher can manage the students' work easily without being busy with the students' paper. 
j. The teacher can score the students' work easily and automatically with an online system.

k. The teacher can check the students' work everywhere since the teacher has devices such as smartphone or laptop and internet connection as well.

Meanwhile, the disadvantages of animation clips as media applied in writing class can be described as follow:

a. It needs more cost because it needs an electronic device such as computer, laptop or smartphone.

b. The teacher can only adopt the Animation Clips from online source because it is difficult to create the Animation Clips by ourselves.

c. It needs a lot of bandwidth to access, so, it will take too long to show over a slow_internet connection.

d. The teachers must have certain programming technology and experiences to implement the animation programs.

e. It really depends on the internet connection and the quality of electronic devices.

f. It is sometimes difficult to apply when the students themselves are low in technology experience.

g. The students will easily cheat, for example using google translate to translate their writing.

\section{CONCLUSION}

According to the implementation of Animation Clips in teaching writing at the eleventh grade students of MA Sunan Giri Gondang in academic year 2017/2018, it can be concluded that the students' writing was getting better after being taught using Animation Clips. It can be seen from the result of writing test, the mean score of pre - test was 74 while the mean score of post - test increased to 79. In general, animation clips is the media that is appropriate for teaching writing. However, there are some advantages and disadvantages of using animation clips as media applied in writing class. Therefore, it is suggested for the English teacher to use animation clips by considering the students condition and 
school facilities such as computer lab and fast internet connection. For further researcher, it is suggested to take this research result as reference for further research dealing with animation clips in different subject and skill such as listening and speaking.

\section{ACKNOWLEDGEMENT}

First I would like to say great thanks unto Allah swt for giving me mercies and blessings to conduct and finish this research. This article is written based on the research report of Hibah Penelitian Dosen Pemula (PDP) in the academic years 2017/2018. Hence, I would like to express my gratitude to DRPM Kemenristekdikti for the facility and support given to me to conduct the research. I also dedicate my deep thanks to STKIP PGRI Tulungagung for giving me a chance to be its affiliation. I am also hugely appreciative to the teachers and students of MA Sunan Giri Gondang for being part of my research. My special thank is given to my beloved wife and son who always become my spirit and motivation to finish this article.

\section{REFERENCES}

Almubark, A. A. (2016). Exploring the Problems Faced by the Teachers in Developing English Writing Skills for the Students in Saudi Arabia. International Journal of English Language Teaching, European Centre for Research Training and Development UK, 4(10), 10-23. Retrieved from www.eajournals.org

Cahyono, B.Y \& Kusumaningrum, S. R. (2011). Practical Techniques for English Language Teaching. Malang: UM Press.

Fareed, M., Ashraf, A., \& Bilal, M. (2016). ESL Learners' Writing Skills: Problems, Factors and Suggestions. Journal of Education \& Social Sciences, 4(2), 81-92. https://doi.org/10.20547/jess0421604201

Harmer, J. (2004). How to Teach Writing. Harlow, United Kingdom: Pearson Education Limited.

Harrison, C., \& Killion, J. (2008). Ten Roles for Teacher Leaders. Educational Leadership, 65(1), 74-77.

Heaton, J. . (1988). Writing English Language Tests. New York: Longman Pub Group.

Kim, S., Yoon, M., Whang, S. M., Tversky, B., \& Morrison, J. B. (2007). The 
effect of animation on comprehension and interest. Journal of Computer Assisted Learning, 23, 260-270. https://doi.org/10.1111/j.13652729.2006.00219.x

Laborda, J. . (2006). Review of "How to Teach Writing." Journal of Applied Psychology, 3(2), 246-248. https://doi.org/http://dx.doi.org/10.1037/h0066619

Naz, A. A., \& Akbar, R. A. (2010). Use of Media for Effective Instruction its Importance : Some Consideration. Journal of Elementary Education, 18(12), 35-40.

PP RI No. 32 th 2013 Tentang Perubahan atas Peraturan Pemerintah Nomor 19 Tahun 2005 Tentang Standar Nasional Pendidikan

Uztosun, M. S. (2006). HEATON , John Brian Writing English Language Tests ( New Edition ) Longman UK Limited, Hong Kong 1990 , XI + 192p . Journal of Theory and Practice in Education, 2(2), 119-122.

Waloyo, E. (1999). The Implementation of Mind Mapping Technique in Teaching Writing: a Case Study At Man 13 Jakarta. ELT-Echo, 2(1), 72-83. 